\title{
Statistical Optimization of Biohydrogen Production Using Food Waste Under Thermophilic Conditions
}

\author{
Fadzillah Ismail, Nor'Aini Abdul Rahman*, Suraini Abd-Aziz, Chong Mei Ling, Mohd Ali \\ Hassan
}

Department of Bioprocess Technology, Faculty of Biotechnology and Biomolecular Sciences, Universiti Putra Malaysia, 43400 UPM Serdang, Selangor, Malaysia

\begin{abstract}
In this study, optimization of biohydrogen production from food waste was investigated using response surface methodology. The fermentation was conducted in a serum bottle with $100 \mathrm{~mL}$ working volume. A Preliminary experiment showed that initial $\mathrm{pH}$ and temperature significantly influenced biohydrogen production. According to the central composite design, the optimal conditions for hydrogen yield were initial $\mathrm{pH}$ of 7.5 and temperature of $55.7^{\circ} \mathrm{C}$, while the optimal conditions for hydrogen production rate were initial $\mathrm{pH}$ of 7.2 and temperature of $55.6^{\circ} \mathrm{C}$. The maximum values for hydrogen yield and hydrogen production rate were $120 \mathrm{~mL} / \mathrm{g}$ carbohydrate and $35.69 \mathrm{~mL} / \mathrm{h}$, respectively.
\end{abstract}

Keywords: Biohydrogen, hydrogen, response surface methodology, food waste.

\section{INTRODUCTION}

Hydrogen gained a lot of attention to replace fossil fuel in the energy and chemical industry. Renewable energy sources should decrease carbon dioxide emission and reduce the consumption of fossil fuel. Energy from hydrogen is most important since it is zero in carbon emission and the end product of it is pure water (Atif et al., 2005) [1]. Among those of the biological processes, the dark fermentation of organic compounds is most preferable because it is technically simple and can use a wide range of organic substances (Hallenback and Benemann, 2002) [2]. The anaerobic fermentation of organic compounds involves two distinct stages: acidogenesis and methanogenesis. Hydrogen is produced as a by-product during the acidogenesis of sugars to organic acids. Hydrogen can be harvested during the acidogenesis process, leaving the remaining acidogenesis product for methanogenesis (Mizuno et al., 2000) [3]. Food waste is a waste composed of raw and cooked materials including food discarded before and during food preparation. In Malaysia, food waste is the most abundant and problematic organic waste. The average amount of food waste generated was $0.8 \mathrm{~kg} / \mathrm{person} /$ day and increased to $1.7 \mathrm{~kg} / \mathrm{person} /$ day in major cities. Food waste makes up almost 30.84-54.04 \% of municipal solid waste depending on the type of residential area (Kathirvale et al., 2003) [4]. Most of the food waste is contributed by domestic and commercial kitchens. Currently, the waste management approach being employed is the landfill technique. However, this process can cause environmental damage such as increasing of methane gas and attracts on flies and vermin. Food waste is carbohydrate-rich

*Address correspondence to this author at the Department of Bioprocess Technology, Faculty of Biotechnology and Biomolecular Sciences, Universiti Putra Malaysia, 43400 Serdang, Senagor, Malaysia; Tel: +6-0389467515; Fax: +6-03-89467510; E-mail: nor_aini@biotech.upm.edu.my and easily hydrosable and these characteristics make it suitable use as substrate in fermentative biohydrogen production (Han and Shin, 2004) [5].

Response surface methodology (RSM), a collection of empirical models and statistical analyses, had been used to study the effects of several factors on hydrogen production rate and hydrogen production yields (Kim et al., 2004) [6]. The concept of RSM has eased the optimization process and it is also a time saving method, which minimizes the errors in determining the effects of the parameters (O-Thong et al., 2008) [7]. Kim et al. (2004) [6] used RSM to investigate the effects of various volatile solid (VS) concentrations and the mixing ratios of two substrates, food waste and sewage sludge on biohydrogen production. The aims of this study were to determine the optimal conditions for biohydrogen production from food waste under thermophilic conditions and the relationship among the factors on biohydrogen production by using RSM.

\section{MATERIALS AND METHODS}

\section{Seed Sludge}

The seed sludge was taken from a settling tank in a local palm oil mill wastewater treatment plant at Serting Hilir, Negeri Sembilan, Malaysia. The $\mathrm{pH}$ and volatile suspended solids (VSS) of the palm oil mill effluent sludge were 7.26 and $84.5 \mathrm{~g} / \mathrm{L}$, respectively. The sludge was heat-treated at $80^{\circ} \mathrm{C}$ for 20 minutes (Lin and Chang, 2004) [8] to inhibit methanogens and to selectively enrich spore forming bacteria (Mohan et al., 2008) [9].

\section{Substrate}

Food wastes were taken from Serumpun College Cafeteria, Universiti Putra Malaysia, Selangor, Malaysia. The food waste was blended with water using an electric blender and then the blended food waste was filtered using a sieve with 
Table 1. Characteristics of Food Waste

\begin{tabular}{|c|c|c|}
\hline Characteristics & Range & Mean \\
\hline \hline $\mathrm{pH}$ & $6.1-6.4$ & 6.25 \\
\hline COD (g/L) & $285.8-376.6$ & 331.2 \\
\hline Total solid (g/L) & $215.7-295.2$ & 255.45 \\
\hline Ammonia (g/L) & $0.145-0.266$ & 0.205 \\
\hline Total sugar (g/L) & $49.26-62.10$ & 55.68 \\
\hline Moisture (\%) & $71-73$ & 72 \\
\hline Protein (\%) & $24.49-31.2$ & 27.845 \\
\hline Fat (\%) & $22.98-28.58$ & 25.78 \\
\hline Fiber (\%) & $1.069-1.34$ & 1.2045 \\
\hline Ash (\%) & $3.99-6.28$ & 5.135 \\
\hline
\end{tabular}

an opening size of $2.00 \mathrm{~mm}$ (Kim et al., 2004) [6]. The characteristics of the food waste are summarized in Table $\mathbf{1}$.

\section{Operating Procedures}

The optimization procedure using response surface methodology contains two parts. The purpose of the 2-level factorial was to determine the significant factors involved and the second part (central composite design) was used to obtain the optimal value for each significant factor. The fermentation was done in a serum bottle with the capacity of $160 \mathrm{~mL}$. The volume of the food waste used for the fermentation is $100 \mathrm{~mL}$. To each bottle, $\mathrm{NaHCO}_{3}$ was added at $0.01 \mathrm{~g} / \mathrm{mL}$ as a buffer to slow down the reduction of $\mathrm{pH}(\mathrm{O}-$ Thong et al., 2008) [7]. Subsequently, the media and the headspace of the bottles were flushed with $\mathrm{N}_{2}$ gas for 10 minutes and the bottles were tightly sealed with aluminum seal caps and rubber septas. The bottles were incubated in a water bath for 24 hours and sampling of the biogas was done at three hour intervals time. The volume of the biogas produced was determined using a $500 \mathrm{cc} \mathrm{mL}$ syringe (Owen et al., 1979) [10]. The gas composition was measured and a sample from the fermentation broth was then analyzed.

\section{Optimization Using Response Surface Methodology}

\section{2-Level Factorial Screening}

The experiment for the 2-level factorial screening was done 18 runs. The variables used were chemical oxygen demand (COD) of the substrate, initial $\mathrm{pH}$, temperature, and inoculum size. The Total COD of the substrate was controlled to be $100 \mathrm{~g} / \mathrm{L}, 150 \mathrm{~g} / \mathrm{L}$ and $200 \mathrm{~g} / \mathrm{L}$. The initial $\mathrm{pH}$ was adjusted at 5, 6 and 7 using $1 \mathrm{M} \mathrm{NaOH}$ and $1 \mathrm{M} \mathrm{H}_{2} \mathrm{SO}_{4}$ and the experiments were done at different incubation temperatures; $50^{\circ} \mathrm{C}, 55^{\circ} \mathrm{C}$ and $60^{\circ} \mathrm{C}$. The inoculum sizes for the fermentation were $15 \%, 22.5 \%$ and $30 \%$. The total carbohy- drate range of the substrate was $25-50 \mathrm{~g} / \mathrm{L}$. Table 2 shows the four variables involved in the design to evaluate their effects on biohydrogen production. Each independent variable was investigated at high (+1) and low (-1) levels. Runs of centre points were included in the design and statistical analysis was used to identify the effects of each variable. The variables having major effects on biohydrogen production were identified on the basis of confidence level above $95 \%$ $(\mathrm{P}<0.05)$.

\section{Central Composite Design}

The second part of the optimization using RSM was the central composite design (CCD) to obtain the optimal value of the tested factor. The CCD runs were developed depending on the number of factors considered for optimization. In this study, the significant factors for biohydrogen production were initial $\mathrm{pH}$ and temperature. The design included 5 centre points and also the variables were set at extreme levels (2 and +2 ). Table 3 shows the actual and the coded levels of the variables tested for biohydrogen production. The experiment for the central composite design was done 21 times. The initial $\mathrm{pH}$ was adjusted to 5,6,7,8 and 9. The incubation temperatures were $45,50,55,60$ and $65^{\circ} \mathrm{C}$. The responses obtained were statistically evaluated and models were built based on variables with confidence levels is more than $95 \%$.

\section{ANALYTICAL METHODS}

The hydrogen, $\mathrm{CH}_{4}, \mathrm{~N}_{2}$ and $\mathrm{CO}_{2}$ contents in the biogas were measured using a gas chromatography (GC, Shimadzhu 17A) with a thermal conductivity detector (TCD) and a $1.83 \mathrm{~m} \times 3.18 \mathrm{~mm}$ (inner diameter) stainless-steel column packed with Porapak Q (80/100 mesh) with molecular sieve $5 \mathrm{~A}$ and $\mathrm{N}_{2}$ as the carrier gas. The temperatures of the injector, detector and column were $100^{\circ} \mathrm{C}, 100^{\circ} \mathrm{C}$ and $50^{\circ} \mathrm{C}$, respectively. The levels of organic acids (lactate, formate, acetate, propionate, n-butyrate and iso-butyrate) were analyzed using a high performance liquid chromatography (Shimadzhu LC-10AS with UV-VIS detector SPD-10A) with $4 \mathrm{mM}$ $\mathrm{H}_{2} \mathrm{SO}_{4}$ as mobile phase at a flowrate of $0.6 \mathrm{~mL} / \mathrm{min}$. The liquid samples were centrifuged, and the supernatants were used for the analysis of organic acids using HPLC. The carbohydrate levels was analysed using the Phenol-Sulphuric acid method (Dubois et al., 1956) [11].

\section{DATA ANALYSIS}

The Modified Gompertz Equation (1) was used to describe the hydrogen production in the batch test (Lee et al., 2001) [12].

$$
H=P \times \exp \left[-\exp \left\{\frac{R m}{p}(\lambda-t) e+1\right\}\right],
$$

Where $H$ is cumulative hydrogen production $(\mathrm{mL}), P$ is ultimate hydrogen production $(\mathrm{mL}), R m$ is hydrogen production rate $(\mathrm{mL} / \mathrm{h}), \lambda$ is lag-phase time (hours), and $e$ is exponential 1 .

In this study, the Modified Gompertz Eq. (1) was used to fit the cumulative hydrogen production to obtain $H, R m$ and $\lambda$. The hydrogen production yield was calculated by dividing the cumulative hydrogen by the amount of carbohydrate consumed during the fermentation. 
Table 2. Coded and Real Values for Screening by 2-Level Factorial Design

\begin{tabular}{|c|c|c|c|c|c|}
\hline & Variable & Unit & $\mathbf{- 1}$ & $\mathbf{0}$ \\
\hline \hline $\mathrm{A}$ & $\mathrm{COD}$ & $\mathrm{g} / \mathrm{L}$ & 100 & 150 & 200 \\
\hline $\mathrm{B}$ & Initial $\mathrm{HH}$ & 5 & 6 & 7 \\
\hline $\mathrm{C}$ & Temperature & ${ }^{\circ} \mathrm{C}$ & 50 & 55 & 60 \\
\hline $\mathrm{D}$ & Inoculum Size & $\%(\mathrm{v} / \mathrm{v})$ & 15 & 22.5 & 30 \\
\hline
\end{tabular}

Table 3. Coded and Real Values of Variables Selected for CCD

\begin{tabular}{|c|c|c|c|c|c|c|c|}
\hline & Variable & Unit & $\mathbf{- 2}$ & $\mathbf{- 1}$ & $\mathbf{0}$ & $\mathbf{+ 1}$ \\
\hline \hline $\mathrm{A}$ & Initial pH & & 5 & 6 & 7 & 8 & 9 \\
\hline $\mathrm{B}$ & Temperature & ${ }^{\circ} \mathrm{C}$ & 45 & 50 & 55 & 60 \\
\hline
\end{tabular}

Eq. (2) was used to fit the experimental data obtained in the 2-level factorial design.

$\mathrm{Y}=\mathrm{X}_{\mathrm{O}}+\mathrm{X}_{1} \mathrm{~A}+\mathrm{X}_{2} \mathrm{~B}+\mathrm{X}_{3} \mathrm{C}+\mathrm{X}_{4} \mathrm{D}+\mathrm{X}_{12} \mathrm{AB}+\mathrm{X}_{13} \mathrm{AC}+$ $\mathrm{X}_{14} \mathrm{AD}+\mathrm{X}_{23} \mathrm{BC}+\mathrm{X}_{24} \mathrm{BD}$

$+\mathrm{X}_{34} \mathrm{CD}+\mathrm{X}_{123} \mathrm{ABC}+\mathrm{X}_{124} \mathrm{ABD}+\mathrm{X}_{134} \mathrm{ACD}+\mathrm{X}_{234} \mathrm{BCD}$

where $\mathrm{Y}$ is the response, $\mathrm{A}, \mathrm{B}, \mathrm{C}$ and $\mathrm{D}$ are the actual values, $\mathrm{Xo}$ is a constant, $\mathrm{X}_{1}, \mathrm{X}_{2}, \mathrm{X}_{3}$ and $\mathrm{X}_{4}$ are the linear coefficients, $X_{12}, X_{13}, X_{14}, X_{23}, X_{24}, X_{34}, X_{123}, X_{124}, X_{134}$ and $X_{234}$ are the interactive coefficients.

A quadratic model (3) was used to fit the experimental data obtained in the central composite design.

$Y=\mathrm{X}_{\mathrm{O}}+\mathrm{X}_{1} \mathrm{~A}+\mathrm{X}_{2} \mathrm{~B}+\mathrm{X}_{12} \mathrm{AB}+\mathrm{X}_{11} \mathrm{~A}^{2}+\mathrm{X}_{22} \mathrm{~B}^{2}$

where $Y$ is the response, $\mathrm{A}$ and $\mathrm{B}$ are the actual values, $\mathrm{Xo}$ is constant, $X_{1}$ and $X_{2}$ are linear coefficients, $X_{12}$ is the interactive coefficient and $X_{11}$ and $X_{22}$ are quadratic coefficients.

Analysis of variance (ANOVA) was conducted to test the significance of the fitting model for the experimental data, as well as the significance of the linear terms, interactive terms and the quadratic terms. The parameters were diagnosed by correlation coefficient, $\mathrm{R}^{2}, 95 \%$ confidence limit, F-value and P-value. In general, the model was considered to be efficient and workable if it had a significant F-value and good $\mathrm{R}^{2}$ (correlation coefficient). The conditions that could give maximum biohydrogen production were predicted using numerical optimization contained in the Design-Expert 7.0 software (Stat-Ease Inc.). Only the variables considered in model building were varied for prediction, other insignificant variables were maintained at constant values (' 0 ' coded level) as in the 2-level factorial design.

\section{RESULTS AND DISCUSSION}

The hydrogen production curves from the fermentation were subjected to the eq. (1). The hydrogen production po- tential, $P$ ( $\mathrm{mL} \mathrm{H}_{2} / 100 \mathrm{~mL}$ substrate), correlation coefficient, $\mathrm{R}^{2}$ and Rate, $R m$ (mL/day) can be obtained from the equation (1). The values of hydrogen production rate, $\mathrm{Rm}$ and yield were subjected to the response surface methodology to evaluate the relationship among the studied factors and responses. The final $\mathrm{pHs}$ after 24 hours incubation were in the range of $3.88-5.56$.

\section{Two-Level Factorial Design}

All of the 18 runs in the 2-level factorial design successfully produced hydrogen gas through the fermentation and the cumulative hydrogen production curves from all the runs were well-described by Eq. (1). Table 4 shows the $\mathrm{R}^{2}$ of the hydrogen production curve obtained from Eq. (1) and results of hydrogen potential, yield and hydrogen production rate. The results showed that the correlation coefficients, $\mathrm{R}^{2}$, for all the runs were larger than 0.9768 . The maximum hydrogen production potential, yield and rate $248.9 \mathrm{~mL} / 100 \mathrm{~mL}$ substrate, $164.3 \mathrm{~mL} / \mathrm{g} \mathrm{CHO}$ and $38.91 \mathrm{~mL} / \mathrm{h}$, respectively and the minimum were $0.8 \mathrm{~mL} / 100 \mathrm{~mL}$ substrate, $3.5 \mathrm{~mL} / \mathrm{g}$ $\mathrm{CHO}$ and $0.17 \mathrm{~mL} / \mathrm{h}$, respectively.

Eq. (4) was obtained by using Eq. (2) to fit the experimental data of the hydrogen production yield.

$($ Yield $)=-190.44964+6.50291 \mathrm{~A}-124.74207 \mathrm{~B}$ $+10.10027 \mathrm{C}-73.06939 \mathrm{D}$

$+0.30885 \mathrm{AB}-0.15803 \mathrm{AC}-0.03679 \mathrm{AD}+1.25615 \mathrm{BC}$ $+18.23742 \mathrm{BD}$

$+1.10039 \mathrm{CD}+0.012433 \mathrm{ABC}-8.47 \mathrm{E}-003 \mathrm{ABD}+1.60 \mathrm{E}-$ 003 ACD - 0.2954 BCD

where $\mathrm{A}, \mathrm{B}, \mathrm{C}$ and $\mathrm{D}$ are the actual values of substrate concentration $\mathrm{COD}$, initial $\mathrm{pH}$, temperature and inoculum size, respectively.

The ANOVA analysis (Table 5) shows that the prob $>\mathrm{F}$ values for the model were significant for both responses (rate $=p<0.05$, yield $=p<0.05)$. Correlation coefficient, $R^{2}$ for the 
Table 4. Kinetics Parameters for Hydrogen Production Calculated from Eq. (1)

\begin{tabular}{|c|c|c|c|c|c|c|c|c|}
\hline RUN & $\begin{array}{c}\text { Cod Substrate } \\
(\mathrm{g} / \mathrm{L})\end{array}$ & Initial PH & $\begin{array}{c}\text { Temperature } \\
\left({ }^{\circ} \mathrm{C}\right)\end{array}$ & $\begin{array}{c}\text { Inoculum Size } \\
(\% \mathrm{v} / \mathrm{v})\end{array}$ & $\mathbf{R}^{2}$ & $\begin{array}{c}\mathrm{H}_{2} \text { Potential, } P \\
(\mathrm{~mL})\end{array}$ & $\begin{array}{c}\text { Yield } \\
\text { (mL/g } \\
\text { CHO) }\end{array}$ & $\begin{array}{c}\text { Rate, Rm } \\
(\mathbf{m L} / \mathbf{h})\end{array}$ \\
\hline 1 & 100 & 5 & 50 & 15 & 0.9982 & 26.6 & 19.5 & 5.79 \\
\hline 2 & 200 & 5 & 50 & 15 & 0.9993 & 80.2 & 44.8 & 18.83 \\
\hline 4 & 200 & 7 & 50 & 15 & 0.9991 & 248.9 & 96.4 & 32.25 \\
\hline 5 & 100 & 5 & 60 & 15 & 0.9999 & 49.2 & 64.3 & 10.09 \\
\hline 6 & 200 & 5 & 60 & 15 & 0.9998 & 2.0 & 3.5 & 0.38 \\
\hline 9 & 100 & 5 & 50 & 30 & 0.9920 & 50.3 & 28.3 & 8.9 \\
\hline 10 & 200 & 5 & 50 & 30 & 0.9981 & 61.1 & 40.9 & 16.59 \\
\hline 11 & 100 & 7 & 50 & 30 & 0.9998 & 234.1 & 125.6 & 38.78 \\
\hline 12 & 200 & 7 & 50 & 30 & 0.9992 & 194.8 & 164.3 & 38.91 \\
\hline 13 & 100 & 5 & 60 & 30 & 0.9979 & 26.9 & 28.5 & 8.64 \\
\hline 14 & 200 & 5 & 60 & 30 & 0.9768 & 0.8 & 7.7 & 0.17 \\
\hline
\end{tabular}

rate was 0.9887 and the yield was 0.9930 . The results of the prob $>\mathrm{F}$ and the correlation coefficient showed that the model was good. However, for the variables, only initial $\mathrm{pH}$ and temperature were significant factors $(\mathrm{p}<0.05)$ for hydrogen production potential and yield. This was in agreement with a previous report that showed temperature and initial $\mathrm{pH}$ gave impacts on fermentative hydrogen production individually and interactively (Wang and Wan, 2008) [13]. The maximum hydrogen production potential and yield were 248.9 $\mathrm{mL}$ and $164.3 \mathrm{~mL} / \mathrm{g} \mathrm{CHO}$, respectively. The maximum biohydrogen production occurred at substrate concentration of $200 \mathrm{~g} / \mathrm{L}$ COD, temperature of $50^{\circ} \mathrm{C}$ and initial $\mathrm{pH}$ 7. However, for maximum hydrogen production potential, the appropriate inoculum size was $15 \%(\mathrm{v} / \mathrm{v})$ while for yield it was $30 \%(\mathrm{v} / \mathrm{v})$.

\section{Central Composite Design}

Table 6 shows the results of the hydrogen potential, yield and rate of hydrogen production in the central composite design. At lower temperature $\left(<45^{\circ} \mathrm{C}\right)$, the results showed that no hydrogen was produced in run 13 and 14 . The other runs successfully produced hydrogen throughout the fermentation and the hydrogen production curves were fitted to the
Eq. (1). All the correlation coefficients, $\mathrm{R}^{2}$, were larger than 0.9938 as shown in Table $\mathbf{6}$. The results of yield and rate were subjected to Eq. (3).

\section{Effects of Initial pH and Temperature on Hydrogen Pro- duction Yield}

Eq. (5) was obtained by using Eq. (3) to fit the experimental data of hydrogen production yield.

$($ Yield $)=-3557.82+211.03 \mathrm{~A}+130.37 \mathrm{~B}-0.60 \mathrm{AB}-11.8 \mathrm{~A}^{2}$ $-0.88 \mathrm{~B}^{2}$

where $\mathrm{A}$ and $\mathrm{B}$ are the actual values of the initial $\mathrm{pH}$ and temperature, respectively.

ANOVA of the fitting model (Table 7) shows that the model was highly significant $(\mathrm{p}<0.01)$, while the lack of fit was not significant $(\mathrm{p}>0.05)$. Correlation coefficient, $\mathrm{R}^{2}$, was 0.8823 , which could explain $88.23 \%$ of the variability of the response variable. All these show the Eq. (4) could describe the effect of temperature and initial $\mathrm{pH}$ on the hydrogen production yield. ANOVA of the fitting model (Table 7) also shows the linear, quadratic and interactive effects between temperature and initial $\mathrm{pH}$ on hydrogen production yield. The linear and quadratic effect were significant $(\mathrm{p}<0.05)$. 
Table 5. ANOVA Analysis for the Hydrogen Production Potential and Yield

\begin{tabular}{|c|c|c|c|c|}
\hline \multirow{2}{*}{ Source } & \multicolumn{2}{|c|}{ Rate } & \multicolumn{2}{|c|}{ Yield } \\
\hline & F-Value & Prob $>$ F & F-Value & Prob $>$ F \\
\hline Model & 29.07 & 0.0026 & 20.4 & 0.0477 \\
\hline $\begin{array}{l}\text { Substrate concentration } \\
\qquad(\mathrm{g} / \mathrm{L})\end{array}$ & 3.05 & 0.1557 & 2.2 & 0.276 \\
\hline Initial $\mathrm{pH}$ & 95.99 & 0.0006 & 64.28 & 0.0143 \\
\hline Temperature $\left({ }^{\circ} \mathrm{C}\right)$ & 124.44 & 0.0004 & 68.49 & 0.0143 \\
\hline Inoculum size $(\% \mathrm{v} / \mathrm{v})$ & 8.82 & 0.0411 & 1.62 & 0.3305 \\
\hline $\mathrm{R}^{2}$ & \multicolumn{2}{|c|}{0.9887} & \multicolumn{2}{|c|}{0.9930} \\
\hline
\end{tabular}

(Prob $>\mathrm{F}$ less than 0.05 indicate that the model terms are significant)

Table 6. Kinetics Parameters of Hydrogen Production Calculated from Eq. (1)

\begin{tabular}{|c|c|c|c|c|c|c|}
\hline Run & Initial pH & Temperature $\left({ }^{\circ} \mathrm{C}\right)$ & $\mathbf{R}^{2}$ & $\mathbf{H}_{2}$ Potential, $p(\mathrm{~mL})$ & Yield (mL/g CHO) & Rate, $R m(\mathrm{~mL} / \mathrm{h})$ \\
\hline 1 & 6 & 50 & 0.9996 & 97 & 51 & 5.64 \\
\hline 3 & 8 & 50 & 0.9994 & 97 & 87 & 11.36 \\
\hline 5 & 6 & 60 & 0.9968 & 64 & 83 & 8.96 \\
\hline 6 & 6 & 60 & 0.9999 & 110 & 73 & 23.50 \\
\hline 7 & 8 & 60 & 0.9999 & 177 & 117 & 26.05 \\
\hline 8 & 8 & 60 & 0.9981 & 138 & 89 & 15.30 \\
\hline 11 & 9 & 55 & 0.9999 & 95 & 82 & 7.44 \\
\hline 12 & 9 & 55 & 0.9998 & 80 & 62 & 5.65 \\
\hline 13 & 7 & 45 & 0 & 0 & 0 & 0 \\
\hline 14 & 7 & 45 & 0 & 0 & 0 & 0 \\
\hline 15 & 7 & 65 & 0.9968 & 16 & 22 & 3.27 \\
\hline 16 & 7 & 65 & 0.9938 & 16 & 24 & 3.54 \\
\hline
\end{tabular}

This indicated that these terms had impact on hydrogen production yield. However, the results showed that the interactive effects between temperature and initial $\mathrm{pH}$ was not significant $(\mathrm{p}>0.05)$, indicating this term had little impact on hydrogen production yield. The fact that there was insignificant effect between the initial $\mathrm{pH}$ and temperature on hydrogen yield suggested that these factors did not affect each other. 
Table 7. ANOVA of Fitting Model for Hydrogen Production Yield

\begin{tabular}{|c|c|c|c|c|c|}
\hline Source & Sum of Squares & Degree of Freedom & Mean square & F- Value & P-Value \\
\hline Model & 22625.85 & 5 & 4525.17 & 22.49 & $<0.0001$ \\
\hline A & 3220.17 & 1 & 3220.17 & 16.00 & 0.0012 \\
\hline B & 1320.17 & 1 & 11320.17 & 6.56 & 0.0217 \\
\hline $\mathrm{AB}$ & 72.00 & 1 & 72.00 & 0.36 & 0.5587 \\
\hline A2 & 5103.21 & 1 & 5103.21 & 25.36 & 0.0001 \\
\hline B2 & 17795.52 & 1 & 17795.52 & 88.43 & $<0.0001$ \\
\hline Residual & 3018.72 & 15 & 201.25 & & \\
\hline Lack of Fit & 1392.02 & 3 & 464.01 & 3.42 & 0.0526 \\
\hline Pure Error & 1626.70 & 12 & 135.56 & & \\
\hline Cor Total & 25644.57 & 20 & & & \\
\hline
\end{tabular}

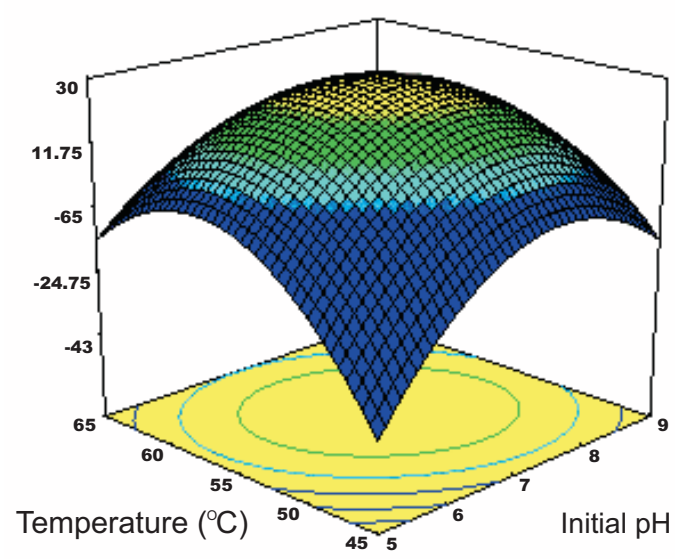

Fig. (1). Response surface plot for hydrogen production yield.

The maximum hydrogen yield obtained of $120 \mathrm{~mL} / \mathrm{g}$ carbohydrate consumed, at a temperature of $55.7^{\circ} \mathrm{C}$ and an initial pH 7.5 was higher when compared to Zhang et al. (2003) [14] who reported that the yield obtained was $92 \mathrm{~mL} / \mathrm{g}$ carbohydrate using wastewater containing starch as a substrate at an initial $\mathrm{pH} 6.0$ and temperature of $55^{\circ} \mathrm{C}$ by using conventional method (one-factor-at-a-time). It was suggested that food waste may contain high concentration of carbohydrate $(200 \mathrm{~g} / \mathrm{L})$ and at thermophilic conditions, a high yield of hydrogen was observed. High hydrogen production was also observed under thermophilic conditions when compared to mesophilic conditions (O-Thong et al., 2008) [7]. However, the biohydrogen yield obtained in this study was slightly lower compared to Kim et al. (2004) [6] and this might be due to the uncontrolled $\mathrm{pH}$ during the hydrogen fermentation.

Fig. (1) shows the response surface plot of the model based on Eq. (4) for hydrogen production yield. The maximum hydrogen production yield could be obtained inside the design boundary. The yield increased with the increase of the initial $\mathrm{pH}$ and temperature until the optimal value and then decreased with further increases of the initial $\mathrm{pH}$ and temperature.

\section{Effects of Initial pH and Temperature on Hydrogen Pro- duction Rate}

Eq. (6) was obtained by using Eq. (3) to fit the experimental data of hydrogen production rate.

$($ Rate $)=-1347.39+115.87 \mathrm{~A}+34.61 \mathrm{~B}-0.46 \mathrm{AB}-6.30 \mathrm{~A}^{2}-$ $0.28 \mathrm{~B}^{2}$

where $\mathrm{A}$ and $\mathrm{B}$ are the actual values of initial $\mathrm{pH}$ and temperature, respectively.

ANOVA of the fitting model (Table 8) shows the model was highly significant $(\mathrm{p}<0.01)$, while the lack of fit was not significant ( $p>0.05$ ), correlation coefficient $\left(R^{2}\right)$ was 0.8475 , which could explain $84.75 \%$ of the variability of the response variable. Eq. (5) could describe the effects of initial $\mathrm{pH}$ and temperature on hydrogen production rate. ANOVA of the fitting model (Table 8) also shows the linear effect and the quadratic effect of temperature and initial $\mathrm{pH}$, and the interactive effect between temperature and initial $\mathrm{pH}$. The quadratic effect of the temperature and initial $\mathrm{pH}$ was highly significant $(\mathrm{p}<0.01)$ indicating that these terms greatly affect the hydrogen production rate. However, the linear effect and the interactive effect between temperature and initial $\mathrm{pH}$ were not significant $(p>0.05)$ indicating that these terms had little impacts on the hydrogen production rate.

Subsequently, the maximum hydrogen production rate obtained was $35.69 \mathrm{~mL} / \mathrm{h}$ at a temperature of $55.6^{\circ} \mathrm{C}$ and initial pH 7.2. Wang et al. (2008) [13] reported that the hydrogen production rate obtained was $28.9 \mathrm{~mL} / \mathrm{h}$ at a temperature of $39.3^{\circ} \mathrm{C}$, initial $\mathrm{pH} 7.0$ and glucose concentration of $26.8 \mathrm{~g} / \mathrm{L}$. Kim et al. (2004) [6] found the highest hydrogen production rate to be $24.85 \mathrm{~mL} / \mathrm{h}$ using co-digestion of food waste and sewage sludge as a substrate in mesophilic conditions. A hydrogen production rate of $1.9 \mathrm{~mL} / \mathrm{h}$ was reported by Zhang et al. (2003) [14] at initial pH 7.0 and temperature of $55^{\circ} \mathrm{C}$ using wastewater containing starch as a substrate. All the experiments reported were done in small scale batch mode using carbohydrate based material as a substrate. 
Table 8. ANOVA of Fitting Model for Hydrogen Production Rate

\begin{tabular}{|c|c|c|c|c|c|}
\hline Source & Sum of Squares & Degree of Freedom & Mean Square & F- Value & 16.67 \\
\hline \hline Model & 2511.10 & 5 & 502.22 & 3.67 & 3.39 \\
\hline A & 110.51 & 1 & 110.51 & 1.42 & 0.0747 \\
\hline B & 102.09 & 1 & 42.78 & 47.65 & 0.0855 \\
\hline AB & 42.78 & 1 & 1435.88 & 59.35 & $<0.0001$ \\
\hline A2 & 1435.88 & 1 & 1788.17 & 30.13 & $<0.0001$ \\
\hline B2 & 1788.17 & 1519 & 59.80 & 2.63 \\
\hline Residual & 451.97 & 3 & 22.71 & & 0.0978 \\
\hline Lack of Fit & 179.40 & 12 & & \\
\hline Pure Error & 272.57 & 20 & & \\
\hline Cor Total & 2963.07 & & & \\
\hline
\end{tabular}

Wang et al. (2008) [13] and Zhang et al. (2003) [14] observed initial $\mathrm{pH} 7$ as the optimal $\mathrm{pH}$ for hydrogen production rate using the conventional method.

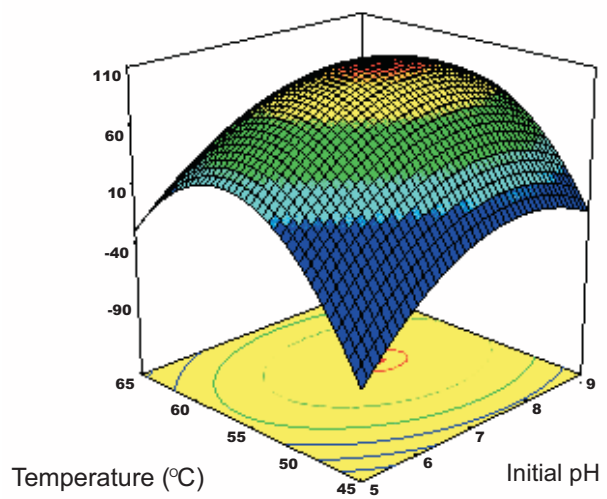

Fig. (2). Response surface plot for hydrogen production rate.

Fig. (2) shows the response surface plot of the model based on Eq. (5) for hydrogen production rate. The maximum hydrogen production rate could be achieved within the design boundary. The hydrogen production rate increased with the increase of initial $\mathrm{pH}$ and temperature until the optimal level, and then the hydrogen production rate decreased with further increases of initial $\mathrm{pH}$ and temperature.

\section{Organic Acids Production}

Fermentative biohydrogen normally is related with organic acids production throughout the fermentation. Hydrogen can be produced either from carbohydrates, proteins and lipids during the acidogenesis and the acetogenesis phases concurrently with the production of organic acids (Mohan et al., 2008) [9]. There is a reduction of carbohydrate concentration of about $7 \%$ to $36 \%$ which shows that the microorganism used the carbohydrates for the production of hydrogen instead of using the proteins and lipids. Lay et al., (2003) [15] reported that proteins and lipids could hardly produce hydrogen. The production of organics acids during fermentative biohydrogen is important to assess the fermentation process. Furthermore, the organic acids produced can be used as substrates for photosynthetic biohydrogen production (Kim et al., 2004) [6]. Table 9 shows the production of organic acids after fermentative hydrogen production for 24 hours. The table shows that the organic acids produced were lactic acid followed by acetic acid and n-butyric acid. Among the organic acids, lactic acid was the highest organic acid produced for each run. The highest organic acids production was $24.33 \mathrm{~g} / \mathrm{L}$ at a temperature of $50^{\circ} \mathrm{C}$, substrate concentration of $200 \mathrm{~g} / \mathrm{L}$, initial $\mathrm{pH} 7.0$ and inoculum size of $15 \%(\mathrm{v} / \mathrm{v})$. Normally, butyric and acetic acids were the organic acids that favor the production of biohydrogen, and lactic acid was known to disfavor hydrogen production $(\mathrm{O}$ Thong et al., 2008, Monika et al., 2009 and Ren et al., 2006) $[7,16,17]$. The presence of high lactic acid concentration corresponded with low production of hydrogen.

\section{CONCLUSIONS}

Temperature and initial $\mathrm{pH}$ had significant impacts on fermentative biohydrogen production individually and interactively according to the 2-level factorial design study. The central composite design study showed the optimal conditions for biohydrogen production yield to be initial $\mathrm{pH} 7.5$ and temperature of $55.7^{\circ} \mathrm{C}$. The maximum hydrogen yield was $120 \mathrm{~mL} / \mathrm{g} \mathrm{CHO}$. The maximum hydrogen production rate of $35.69 \mathrm{~mL} / \mathrm{h}$ was obtained at initial $\mathrm{pH} 7.2$ and temperature of $55.6^{\circ} \mathrm{C}$. The response surface methodology was useful for optimizing the biohydrogen production process and the predicted values under the optimized conditions were highly reproducible. The Modified Gompertz equation was successfully described the progress of cumulative biohydrogen production in the experiment.

\section{ACKNOWLEDGEMENT}

The authors would like to thank the Ministry of Science, Technology, and Innovation (MOSTI), Malaysia for the grant (R4GA 05/01/07-0195R4). 
Table 9. Organic Acids Produced from Biohydrogen Fermentation after 24 Hours

\begin{tabular}{|c|c|c|c|c|c|c|c|}
\hline Runs & \multicolumn{4}{|c|}{ Sample } & \multicolumn{3}{|c|}{ Organic Acids } \\
\hline 2 & 200 & 5 & 50 & 15 & 10.22 & 3.04 & - \\
\hline 3 & 100 & 7 & 50 & 15 & 4.60 & 3.10 & 1.51 \\
\hline 5 & 100 & 5 & 60 & 15 & 2.69 & 2.48 & 2.30 \\
\hline 6 & 200 & 5 & 60 & 15 & 2.83 & 1.32 & - \\
\hline 7 & 100 & 7 & 60 & 15 & 2.34 & 1.33 & 1.03 \\
\hline 8 & 200 & 7 & 60 & 15 & 5.61 & 2.94 & - \\
\hline 9 & 100 & 5 & 50 & 30 & 3.18 & 1.07 & 4.11 \\
\hline 12 & 200 & 7 & 50 & 30 & 13.41 & 7.38 & - \\
\hline 13 & 100 & 5 & 60 & 30 & 1.13 & 1.15 & 0.89 \\
\hline 14 & 200 & 5 & 60 & 30 & 3.85 & 1.13 & - \\
\hline 15 & 100 & 7 & 60 & 30 & 3.38 & 1.53 & 0.21 \\
\hline 16 & 200 & 7 & 60 & 30 & 9.15 & 1.92 & - \\
\hline 17 & 150 & 6 & 55 & 22.5 & 3.18 & 3.14 & - \\
\hline
\end{tabular}

\section{REFERENCES}

[1] Atif, A.A.Y.; Fakhru'l-Razi, A.; Ngan, M.A.; Morimoto, M.; Iyuke, S.E.; Veziroglu, N.T. Fed-batch production of hydrogen from palm oil mill effluent using anaerobic microflora. Int. J. Hydrogen Energy, 2005, 30,1393-1397.

[2] Hallenbeck, P.C.; Benemann, J.R. Biological hydrogen production; fundamentals and limiting processes. Int. J. Hydrogen Energy, 2002, 27, 1185-1193.

[3] Mizuno, O.; Dinsdale, R.; Hawkes, F.R.; Hawkes, D.C.; Noike, T. Enhancement of hydrogen production from glucose by nitrogen gas sparging. Bioresource Technol., 2000, 73(1), 59-65.

[4] Kathirvale, S.; Yunus, M.N.M.; Sopian, K.; Samsuddin, A.H. Energy potential from municipal solid waste in Malaysia. Renewable Energy, 2003, 29, 559-567.

[5] Han, S.K.; Shin, H.S. Enhanced acodogenic fermentation of food waste in a continous-flow reactor. Waste Manage. Resource, 2004, 20, 110-118.

[6] Kim, S.H.; Han, S.K.; Shin, H.S. Feasibility of biohydrogen production by anaerobic co-digestion of food waste and sewage sludge. Int. J. Hydrogen Energy, 2004, 29, 1607-1616.

[7] O-Thong, S.; Prasertsan, P.; Intrasungkha, N.; Dhamwichukorn, S.; Birkeland, N-K. Optimization of simultaneous thermophilic fermentative hydrogen production and COD reduction from palm oil mill effluent by thermoanaerobacterium-rich sludge. Int. J. Hydrogen Energy, 2008, 33, 1221-1231.

[8] Lin, C.Y.; Chang, R.C. Fermentative hydrogen production at ambient temperature. Int. J. Hydrogen Energy, 2004, 29, 715-720.
[9] Mohan, S.V.; Babu, V.L.; Sarma, P.N. Effect of various pretreatment methods on anaerobic mixed microflora to enhance biohydrogen production utilizing dairy wastewater as substrate. Bioresource Technol., 2008, 99, 59-67.

[10] Owen, W.F.; Stuckey, D.C.; Healy, Jr. J.B.; Young, L.Y.; McCarty, P.L. Bioassay for monitoring biochemical methane potential and anaerobic toxicity. Water Reserv., 1979, 13, 485-493.

[11] Dubois, M.; Gilles, K.A.; Hamilton, J.K.; Rebers, P.A.; Smith, F. Colorimetric method for determination of sugars and related substances. Anal. Chem., 1956, 28,350-356.

[12] Lee, Y.J.; Miyahara, T.; Noike, T. Effect of iron concentration on hydrogen fermentation. Bioresource Technol., 2001, 80, 227-231.

[13] Wang, J.; Wan, W. Optimization of fermentative hydrogen production process by response surface methodology. Int. J. Hydrogen Energy, 2008, 33, 6796-6984.

[14] Zhang, T.; Liu, H.; Fang, H.H.P. Biohydrogen production from starch in wastewater under thermophilic condition. J. Environ. Manage., 2003, 69,149-156

]15] Lay, J.J.; Fan, K.S.; Chang, J.I.; Ku, C.H. Influence of chemical nature of organic wastes on their conversion to hydrogen by heatshocked digested sludge. Int. J. Hydrogen Energy, 2003, 28, 13611367

[16] Monika, T.; Skonieczny, Viviane, Y. Biohydrogen production from wastewater by Clostridium beijerinckii: effect of $\mathrm{pH}$ and substrate concentration. Int. J. Hydrogen Energy, 2009, 34, 3288-3294.

[17] Ren, N.; Li, J.; Li, B.; Wang, Y.; Liu, S. Biohydrogen production from molasses by anaerobic fermentation with a pilot-scale bioreactor system. Int. J. Hydrogen Energy, 2006, 31, 2147-2157.

(C) Ismail et al.; Licensee Bentham Open.

This is an open access article licensed under the terms of the Creative Commons Attribution Non-Commercial License (http://creativecommons.org/licenses/by-nc/3.0/) which permits unrestricted, non-commercial use, distribution and reproduction in any medium, provided the work is properly cited. 